\title{
Dileme oko primene dvojne antitrombocitne terapije kod bolesnika sa akutnim koronarnim sindromom i nakon perkutane koronarne intervencije
}

\author{
Slobodan Obradovići, ${ }^{1,2}$ Mila Kovačević ${ }^{3}$ \\ ${ }^{1}$ Klinika za kardiologiju i urgentnu internu medicinu, Vojnomedicinska akademija, ${ }^{2}$ Medicinski fakultet Univerziteta \\ odbrane, ${ }^{3}$ Institut za kardiovaskularne bolesti Vojvodine, Medicinski fakultet Univerziteta u Novom Sadu
}

Sažetak

\begin{abstract}
Godine 2017 su objavljene i Evropske preporuke za korišćenje dvojne antitrombocitne terapije u kardiologiji. Zbog izuzetne važnosti i složenosti koja proizilazi iz velikog broja istraživanja, radna grupa Evropskog kardiološkog društva za dvojnu antitrombocitnu terapiju u koronarnoj bolesti je napisala fokusirani dokument posvećen najnovijim saznanjima kada je u pitanje korišćenje dvojne antitrombocitne terapije. Međutim, ostaju brojne dileme i svakodnevni klinički scenariji u kojima se lekari, kako interventni kardiolozi, tako i najširi spektar specijalnosti, moraju snalaziti. Ovaj tekst pokušava da sažme najvažnije dileme vezane za korišćenje dvojne antitrombocitne terapije i da da kritičan osvrt na preporuke kako bi bila jasnija određena ograničenja koja se navode i povoljno uticala na odlučivanje vezano za primenu dvojne antitrombocitne terapije u situacijama gde nema dovoljno podataka
\end{abstract}

adašnje preporuke za akutni infarkt bez ST elevaci$\mathrm{je}^{1}$, preporuke za akutni infarkt sa ST elevacijom ${ }^{2} \mathrm{i}$ fokus preporuke za dvojnu antitrombocitnu terapiju (DAT) ${ }^{3}$, kao klasu I preporuka savetuju primenu DAT pri prvom medicinskom kontaktu, tj. od trenutka kada postoji ozbiljna sumnja da se radi o akutnom koronarnom sindromu (AKS). Kada su u pitanju bolesnici sa STEMI, za njih se savetuje bilo koja kombinacija DAT (aspirin $+\mathrm{P}_{2} \mathrm{Y}_{12}$ receptor antagonista) sa tim da se daje prednost tikagreloru i prasugrelu u odnosu na klopidogrel. Realno gledano, ni za ovu preporuku ne postoje dovoljno snažni dokazi jer nema dovoljno velikih randomizovanih studija sa važnim ishodima koje bi dokazale korist od primene DAT i kod ove grupe bolesnika, ali je opšte prihvaćeno da tu terapiju treba dati od onog trenutka kada se postavi dijagnoza STEMI-ja odnosno kada se na EKG-u bolesnika koji ima bolove u grudima vidi elevacija ST segmenta u najmanje dva susedna odvoda i tri kompleksa. Nesavršenost EKG-a tj. naše interpretacije i klasifikacije bolesti je u ovom slučaju upravo dovela do toga da bolesnici sa infarktom zadnjeg zida često ne dobiju DAT ili ovu terapiju dobiju kasnije, jer ovi bolesnici, često nemaju elevaciju ST segmenta u klasičnim EKG odvodima, tako da je za ovu grupu bolesnika, iako je to jasno opisano u Preporukama za STEMI ${ }^{2}$ potrebno pomisliti na infarkt zadnjeg zida kada se nađe depresija (najčešće nishodna) ST segmenta u odvodima V1-V3 (mada je moguće i do V6). Tada se preporučuje snimanje zadnjih odvoda, ${ }^{4}$ što nekada na terenu, od strane hitne medicinske službe nije lako uraditi. Takođe, i STEMI bolesnici sa blokom grane, teško da će prehospitalno dobiti DAT i tu odluku treba ostaviti iskusnim ekipama da je donesu, jer svakako moguće da se ne radi o STEMI kada je EKG težak za interpretaciju.
Kada su u pitanju bolesnici sa akutnim koronarnim sindromom bez ST elevacije, tu je stvar mnogo kompleksnija. lako se prema aktuelnim preporukama za AKS bez ST elevacije preporučuje inicijacija DAT neposredno po postavljanju dijagnoze, za sada ne postoje dokazi za i protiv pretretmana $\mathrm{P}_{2} \mathrm{Y}_{12}$ ihibitorima ${ }^{5,6}$. Za razliku od klopidogrela i tikagrelora za koje nema randomizovanih studija koje bi dale odgovor na optimalno vreme uvođenja ovih lekova u slučaju AKS bez ST elevacije i samim tim nemamo preporuku o pretretmanu ovim lekovima, ACCOAST studija kao jedina randomizovana studija koja je ispitala pretretman sa prasugrelom, ne preporučuje inicijaciju prasugrelom ukoliko koronarna anatomija nije poznata?.

Vrlo su važni strategija i mogućnosti lečenja bolesnika sa AKS bez ST elevacije. Ukoliko se prime u bolnicu koja može da uradi hitnu perkutanu koronarnu intervenciju (PKI) i koja ima mogućnosti za kardiohirurgiju trebalo bi uraditi pažljivu selekciju bolesnika kojima će se dati DAT pre koronarografije. Kada postoji visoka verovatnoća da će bolesnik biti za PKI, a to je u slučaju tranzitorne elevacije ST segmenta ili od ranije poznatog koronarografskog nalaza koji bi ukazao na veću verovatnoću PKI, ili ukoliko bolesnik ima stentove i u periodu je kada bi se mogla očekivati ishemija uzrokovana restenozom, u tim slučajevima treba primeniti DAT pre ulaska u kateterizacionu salu. U slučaju da kod bolesnika očekujemo trosudovnu koronarnu bolest i da je potencijalni kandidat za urgentnu kardiohirurgiju trebalo bi DAT odložiti do trenutka kada se uradi koronarografija i kada se donese odluka o tipu revaskularizacije koja je potrebna. Opet, EKG nalaz koji ukazuje na trosudovnu kornarnu bolest sa elevacijom ST segmenta u aVR i difuznom depresijom ST segmenta kao i od ranije poznat koronarografski nalaz u smislu teške koronarne 
bolesti, sa ili bez stenoze glavnog stabla leve koronarne arterije, mogu nam unapred ukazati da li možemo sa većom verovatnoćom očekivati situaciju da bolesnik sa AKS bez ST elevacije treba da se leči hitnom kardiohirugijom. Doduše, hitna kardiohirurgija je dosta relativan pojam i retko gde se može očekivati da će značajniji broj bolesnika sa AKS bez ST elevacije biti operisan tokom prvog dana hospitalizacije, ali ako je ovaj scenario moguć, trebalo bi voditi računa o prekoronarografskoj primeni DAT. Takođe, postoji i značajan broj bolesnika kod kojih uprkos tegobama i porastu troponina, EKG nije konkluzivan, promene su male, nespecifične i sasvim je moguće da se neće uraditi PKI kod značajnog broja ovih bolesnika, tako da je potrebno proceniti i eventualni rizik od krvarenja, pa kod bolesnika kod kojih je taj rizik povišen, takođe treba izbeći davanje DAT pre koronarografije. S obzirom na brzinu dejstva tikagrelora, kod bolesnika sa nestabilnom anginom se može dati isitnjen tikagrelor $180 \mathrm{mg}$ ili prasugrel $60 \mathrm{mg}$ u kateterizacionoj sali kada se odluči da će se raditi PKI, pacijentu ostaviti uvodnik, i za nekih 2 sata mu uraditi PKI. Ukoliko ustanova ima kangrelor, PKI se može uraditi odmah ali opet uz davanje peroralnih P2Y ${ }_{12}$ antagonista bržeg dejstva. Ukoliko ustanova u kojoj se leči pacijent nema opciju hitne kardiohirurgije postoji još veća opravdanost prekoronarografske upotrebe DAT ali i u tom slučaju trebalo bi voditi računa o šansama da se procedura završi sa PKI i o eventualnom riziku za krvarenje. Ukoliko se pacijent sa AKS bez ST elevacije prima u bolnicu bez opcije za brzu koronarografiju što čini veliki broj bolesnika u Srbiji, tu bi trebalo nekako definisati vreme koronarografije u kontaktu sa PKI centrom i dati DAT (aspirin + tikagrelor) jer ova kombinacija lekova daje najviše šansi da bolesnik ne dobije infarkt do koronarografije.

\section{Prebacivanje sa jednog na drugi P2 $\mathrm{Y}_{12}$ receptor antagonistu}

Prebacivanje sa klopidogrela na tikagrelor se praktično savetuje za sve AKS bolesnike osim za one kojima je neophodna oralna antikoagulantna terapija. To je za sada jedini ispitani smer prevođenja sa jednog na drugi $\mathrm{P}_{2} \mathrm{Y}_{12}$ inhibitor $^{8}$. Za sada se ne savetuje kombinacija oralne antikoagulantne terapije sa potentnijim $\mathrm{P} 2 \mathrm{Y}_{12}$ receptor antagonistima jer se pretpostavlja da bi se time značajno povećala šansa za ozbiljna krvarenja. Takvu kombinaciju (tikagrelor sa oralnom antikoagulantnom terapijom) bi eventualno trebalo rezervisati samo za pacijente koji su imali trombozu stenta na klopidogrelu. Prebacivanje sa tikagrelora na klopidogrel u nekoj kasnijoj fazi lečenja AKS, recimo nakon više od mesec dana, takođe nema mnogo smisla jer postoji kontinuirana korist od tikagrelora u odnosu na klopidogrel u smanjenju ishemijskih događaja u periodu od godinu dana nakon AKS. ${ }^{8}$ Eventualno, ukoliko imamo bolesnika koji je imao krvarenje na tikagreloru (i aspirinu) može se pokušati prevođenje sa tikagrelora na klopidogrel, ili ukoliko imamo bolesnika sa veoma visokim rizikom za krvarenje, možda kod tih bolesnika ima smisla nakon 3-6 meseci zameniti tikagrelor sa klopidogrelom. $U$ smislu određivanja rizika za krvarenje najviše može pomoći PRECISE DAPT skor ${ }^{9}$ koji se može naći u preporukama za DAT i gde vrednost preko 25 označava bolesnike sa viso- kim rizikom za krvarenje. Teoretski bi se ovaj skor mogao koristiti i za prevođenje pacijenata koji imaju povećanu sklonost ka krvarenju sa potentnijih (tikagrelor i prasugrel) P2Y12 receptor antagonista na manje potentan klopidogrel. Ovakva primena skora nije uopšte testirana i bilo bi interesantno sprovesti ovakvo istraživanje.

\section{Kombinovanje antikoagulantne $i$ antitrombocitne terapije}

Kada je u pitanju ova neophodnost, vrlo je važna indikacija za antikoagulantnu terapiju. Ukoliko su u pitanju pacijenti sa veštačkim valvulama, za sada nema dileme i primenjuju se vitamin K antagonisti (VKA). I kod bolesnika sa trombom u komori, pošto za sada nema dovoljno podataka o primeni NOAK-a u ovoj indikaciji, mišljenja smo da bi bilo najuputnije koristiti vitamin $\mathrm{K}$ antagoniste. Takođe i bolesnici kojima treba kombinovana terapija, a imaju teži stepen bubrežne insuficijencije (GFR oko $i$ ispod 15 $\mathrm{ml} / \mathrm{min}$ ) su za vitamin $\mathrm{K}$ antagoniste. Ako su u pitanju indikacije u kojima se NOAK lekovi mogu davati, prevencija tromboembolijskih komplikacija kod atrijalne fibrilacije (AF) (izuzev pacijenata sa AF i umerenom i/ili teškom mitralnom stenozom) i venski tromboembolizam, onda ovi lekovi imaju prednost $\mathrm{u}$ odnosu na vitamin $\mathrm{K}$ antagoniste $^{10}$. Vrlo verovatno je da su novi oralni antikoagulantni lekovi bezbedniji u kombinaciji sa antitrombocitnom terapijom u odnosu na kombinaciju vitamin $\mathrm{K}$ antagonista i antitrombocitinih lekova. U svakom slučaju, trebalo bi što kraće (do mesec dana) sprovoditi trojnu antitrombotičnu terapiju i samo ukoliko je u pitanju ekstremno visok ishemijski rizik (pod tim se podrazumeva i ekstremno visok rizik od smrtnog ishoda u slučaju tromboze stenta ili novog infarkta miokarda) trebalo bi nastaviti trojnu terapiju više od mesec dana od AKS, a najduže šest meseci ${ }^{11}$. U retkim situacijama, kada postoji visok hemoragijski rizik, može se od samog starta započeti sa dvojnom terapijom (klopidogrel i jedan od novih OAK ${ }^{12}$. Za sada je aspirin lek koji bi trebalo prvo isključiti, mada randomizovani podaci na tu temu ne postoje. Od NOAK-a, u dve studije, REDUAL PCl ${ }^{13}$ i PIONEER AF-PCl ${ }^{14}$ su testirane kombinacije antitrombocitnih lekova sa dabigatranom i rivaroksabanom, ali treba imati na umu da su to bili bolesnici nižeg ishemijskog rizika, tj. malo bolesnika je imalo STEMI i NSTEMI kao povod za PKI i da je u tim studijama učestvovalo nedovoljno bolesnika da se proveri ono najvažnije zbog čega se lekovi u stvari i daju, a to je efikasnost i da su uglavnom korišćene kombinovane definicije krvarenja (minor+major), a poznato je da minor krvarenja gotovo da ne utiču na mortalitet i retko i na nastanak novih ishemijskih događaja, tako da sve te podatke treba uzeti prilično sa rezervom. Međutim, ove studije su imale za osnovni cilj da ohrabre primenu NOAK-a uz P2Y $_{12}$ receptor antagoniste, bez aspirina i mišljenja smo da su za sada najizglednije kombinacije rivaroxabana $15 \mathrm{mg}$ uz klopidogrel i kombinacija dabigatrana u dozi od $2 \times 110 \mathrm{mg}$ uz klopidogrel sa što kraćom upotrebom aspirina. Studije sa apiksabanom i edoxabanom nakon PKI su u toku. Uz ove kombinacije lekova bilo bi vrlo poželjno dati inhibitore protonske pumpe.

Sve više pacijenata se pojavljuje koji su na NOAK lekovima sa AKS. U tom slučaju se generalno savetuje nastavak 
terapije NOAK-om, ali to nije tako jednostavno. Kod prijema bolesnika u bolnicu važno je znati da li je i kada je bolesnik popio poslednju dozu NOAK-a. Ukoliko je primljen u periodu kada se očekuje njegovo maksimalno antikoagulantno dejstvo (3-6 sati od uzimanja leka) treba pažljivo dozirati parenteralnu antikoagulantnu terapiju i u tom slučaju najbolje je koristiti nefrakcionisani heparin u nešto manjoj dozi nego od uobičajene, treba izbegavati niskomolekularni heparin. Tikagrelor i prasugrel bi bilo dobro izbeći jer postoji jako malo podataka o primeni ovih lekova u kombinaciji sa NOAK lekovima, a vrlo je verovatno da će postojati značajno veća sklonost ka krvarenjima u odnosu na klopidogrel. Kao i za druge bolesnike, a u ovom slučaju naročito, prednost ima radijalni pristup, pa ukoliko postoji iskusan izvođač radijalnog pristupa, bilo bi uputno da se PKI uradi radijalnim pristupom. Nastavak NOAK-a bi trebalo da bude vrlo pažljiv jer bolesnici primaju kontrast i mogu imati i srčanu slabost u okviru AKS, što sve može dovesti do akutnog pada glomerularne filtracije što je naročito važno kod upotrebe dabigatrana. Dakle, bolesnici koji su hipotenzivni, koji imaju veći rizik za kontrastom indukovanu nefropatiju, oni kod kojih se može očekivati srčana slabost i oni sa već postojećom bubrežnom slabošću trebalo bi veoma pažljivo da se monitorišu i da možda jedno vreme budu na nefrakcionisanom heparinu dok ne postanu potpuno stabilni i dok se ne bude mogla sa većom sigurnošću proceniti bubrežna funkcija.

\section{Pacijent koji krvari na dvojnoj antitrombocitnoj terapiji}

Kod pacijenta koji krvari na DAT važno je nekoliko aspekata. Pre svega, jako je važno proceniti odnos ishemijskog rizika i rizika od ozbiljnih posledica krvarenja. Neophodno je utvrditi vremenski period od izvođenja PKI do početka krvarenja, da li je PKI rađena u okviru AKS ili stabilne koronarne bolesti, da li je implantiran metalni ili lekom obloženi stent, kao i preporučenu dužinu trajanja DAT u tom scenariju. Od nesumnjive važnosti je i stepen težine krvarenja. Svi navedeni faktori uticaće na odluku o potpunom prekidu DAT (u slučaju životno ugrožavajućih krvarenja), prelasku na jedan antiagregacioni lek ili produžetku trajanja DAT uprkos krvarenju.

Vreme od PKI tj. od AKS do krvarenja je od izuzetne važnosti. Kada je u pitanju vrsta stentova, većina DES druge generacije pokazuje veoma nisku trombogenost i za nekoliko stentova postoje podaci da je prekid antiagregacione terapije samo u mesec dana od PKI povezan sa povećanim rizikom od tromboze stenta dok prekid terapije nakon tog vremena nema za posledicu povećanu učestalost tromboza stenta. Preporuku sugerišu najmanje 3 meseca upotrebe DAPT kod bolesnika sa stabilnom koronarnom bolešću i visokim rizikom za krvarenje (iznimno 1 mesec) i najmanje 6 meseci upotrebu DAPT kod bolesnika kojima je PKI urađena u AKS i koji imaju visok rizik za krvarenje.

Vrlo je važno proceniti i veličinu krvarenja i mesto krvarenja. Sva intrakranijalna krvarenja nose veliki rizik od smrtnog ishoda, a naročito intracerebralno krvarenje i taj rizik je veći od rizika za smrtni ishod ako bolesnik dobije infarkt srca, tako da je u tom slučaju neohodan potpuni prekid DAT. Intrakranijalna krvarenja su na svu sreću retka.
Sa druge strane, mnogo češća i po život često opasna su gastrointestinalna i krvarenja. Na DAT su nešto češća krvarenja iz gornjih partija gastrointestinlnog trakta ali i krvarenja iz donjih partija nisu retka. Obično se neka dodatna patologija krije iza gastrointestinalnog krvarenja, bilo da su to erozije, ulkusna bolest, angiodisplazije, divertikuloza, tumori ili hemoroidi. Svaka melena ili hematemeza kod bolesnika na DAT se mora smatrati po život opasnim krvarenjem i veoma je važna hitna endoskopija sa iskusnim endoskopistom koji je u stanju da zaustavi krvarenje. Nekada kada je krvarenje veoma veliko i pacijent je hemodinamski nestabilan treba proceniti pravo vreme za endoskopiju i za to vreme primeniti opšte mere za hemodinamsku stabilizaciju. Uopšteno, transfuzija trombocita i deplazmatisanih eritrocita kod bolesnika koji krvare na DAT neće moći značajnije da pomogne naročito ako su bolesnici pod punim dejstvom lekova. Mogu se u slučaju po život opasnih krvarenja primeniti i nespecifični lekovi kao što su antifibrinolitici, VIla faktor koagulacije, protrombinski kompleks itd, ali treba imati na umu da sva ova terapija može provocirati trombozu i infarkt srca, naročito ako je krvarenje nastalo unutar mesec dana od PKI. Krvarenja iz urogenitalnog trakta takođe nisu retka ali su za razliku od gastrointestinalnog krvarenja često blaža, tj. retko po život opasna. I u tom slučaju je neophodan pregled urologa i ultrazvuk urogenitalnog trakta. U tesnoj saradnji sa gastroenterologom i urologom treba odrediti pravi trenutak za vraćanje DAT i period prekida treba da bude što kraći što je vremenski bliža PKI.

Prema novim DAT preporukama, kada su u pitanju pacijenti na trojnoj terapiji, krvarenja su podeljena u pet grupa (trivijalno, blago, umereno, ozbiljno i životno ugrožavajuće krvarenje), a terapija krvarenja je klasifikovana na opšte mere lečenja krvarenja, na mere koje se odnose na DAT koje su iste kao i za dvojnu terapiju i mere koje se odnose na OAT. U tom slučaju mere koje se odnose na OAT podrazumevaju obustavljanje jedne /naredne doze leka (u slučaju trivijalnog krvarenja), potpunu obustavu OAT i potpunu obustavu sa reverzijom dejstva.

\section{Procena rizika od krvarenja i rizika za ishemijske događaje nakon perkutane koronarne intervencije}

U novim DAPT preporukama dosta pažnje je posvećeno PRECISE DAPT skoru koji je izveden iz velike kohorte bolesnika iz nekoliko PKI studija i eksterno validiran na grupi bolesnika iz PLATO studije koji su lečeni PKI i na grupi bolesnika iz Bern registra PKI bolesnika. Skor uzima u obzir nekoliko parametara koji su se pokazali značajnim za predikciju krvarenja nakon PKI bilo da su one elektivne ili hitne, i to su godine bolesnika, glomerularna filtracija, nivo hemoglobina, broj leukocita u perifernoj krvi i prisustvo ranijeg krvarenja. Kreiran je jednostavan normogram i na osnovu pojedinačnih poena se određuje zbirni broj poena. PRECISE DAPT ${ }^{9}$ je pokazao da ako su bolesnici imali visok rizik od krvarenja (broj poena $\geq 25$ ) nije bilo koristi od produženja DAT nakon 6 meseci od PKI i da su bolesnici imali više krvarenja nego koristi u sprečavanju ishemijskih događaja, a da su bolesnici sa skorom manjim od 25 imali korist od nastavka DAT najmanje još 6 meseci u smi- 
slu značajnog smanjenja ishemijskih događaja u odnosu na krvarenja. Međutim ovaj skor ima i značajna ograničenja. Osnovno je da je malo bolesnika bilo sa STEMI-jem u kohorti koja je služila za kreiranje skora, da su po pravilu isključivani bolesnici koji su imali indikaciju za antikoagulantnu terapiju i velika većina bolesnika je bila na klopidogrelu - preko $88 \%$, tako da je pitanje koliko dobro ovaj skor može da funkcioniše za bolesnike sa STEMI-jem jer se podcenjuje ishemijski rizik, zatim kod bolesnika na potentnijim P2Y 12 receptor antagonistima, kao i kod bolesnika koji imaju indikaciju i za primenu oralne antikoagulantne terapije. Ovaj skor i nije prospektivno testiran da li može da služi za selekciju dužine trajanja DAPT. Tako da je i klasa preporuka Ilb (može se razmotriti upotreba skora kod odlučivanja o dužini DAT) i nivo dokaza B za sada kada je u pitanju korišćenje ovog skora u smislu određivanja dužine DAT (6 meseci ili 12 i više meseci).

Osim ovog skora značajnu pažnju preporuka je imao DAPT skor koji je proistekao iz DAPT studije i kojim se u stvari procenjuje ishemijski rizik nakon što su pacijenti godinu dana bili na DAT i pri tome nisu imali značajnijih događaja (niti krvarenja, niti ishemijskih događaja). DAPT skor se takođe jednostavno izračunava i postoji internet aplikacija za njegovo izračunavanje. On, u stvari treba da preporuči ili da ne preporuči nastavak DAT godinu dana nakon PKI i godinu dana nakon primene DAT. Skor 2 i više išao bi u prilog nastavka terapije i to u dužem vremenskom periodu, a skor ispod 2 bi ukazao na grupu bolesnika kod kojih će biti veće krvarenje i neće biti koristi od nastavka terapije posle godinu dana. Ovde treba podvući da skor u sebi ima negativne poene, godine 75 i više -2 poena i skor 65-74 -1 poen, pa je donekle jasno da kod starijih bolesnika treba dobro razmisliti o nastavku terapije i da je potreban veći broj ishemijskih faktora rizika da bi se kod starijih bolesnika posle godinu dana nastavila DAT. Naravno, i ovde postoje ozbiljni nedostaci DAPT skora. Većina stent tromboza koja se desila u DAPT studiji potiču od tromboza paklitakselom obloženog stenta prve generacije koji se više ne koristi. Opet bilo je malo STEMI bolesnika i činjenica da pacijenti nisu imali značajnijih ni ishemijskih, ni hemoragijskih događaja za vreme od godinu dana nakon PKI, čini da ova kohorta bolesnika ima relativno nizak ishemijski rizik. Takođe, ni ovaj skor nije prospektivno validiran u smislu da li se, ili se ne može primeniti, za odlučivanje o nastavku DAT godinu dana nakon PKI.

\section{Preporuke za bolesnike koji trebaju da se operišu}

Nove preporuke za DAT su vrlo jasne u pogledu prekida pojedinih lekova u odnosu na elektivnu hirurgiju. Prasugrel treba prekinuti 7 dana pre, klopidogrel 5 dana pre i tikagrelor 3 dana pre planirane hirurgije. Mnogo veći problem su hitne hirurške intervencije i trauma. Ukoliko se potreba za hitnom hirurškom intervencijom ukaže unutar 30 dana od PKI treba učiniti sve da se operacija uradi bez prekida DAT ili sa najminimalnijim prekidom. Da li bi u ovom slučaju pomogle transfuzije trombocita i dezmopresin teško je reći ali svakako vredi pokušati. Ukoliko je ikako moguće treba konzervativno tretirati bolesnika i sačekati da prođe najmanje mesec dana od PKI naročito ako je intervencija rađena u akutnom infarktu srca.

\section{Literatura}

1. Roffi M, Patrono C, Collet JP, et al. 2015 ESC Guidelines for the management of acute coronary syndromes in patients presenting without persistent ST-segment elevation: Task Force for the Management of Acute Coronary Syndromes in Patients Presenting without Persistent ST-Segment Elevation of the European Society of Cardiology (ESC). Eur Heart J 2016;37(3):267-315.

2. Ibanez B, James S, Agewall S, et al. 2017 ESC Guidelines for the management of acute myocardial infarction in patients presenting with ST-segment elevation: The Task Force for the management of acute myocardial infarction in patients presenting with ST-segment elevation of the European Society of Cardiology (ESC). Eur Heart J 2018;39(2):119-177.

3 Valgimigli M, Bueno $H$, Byrne RA, et al. 2017 ESC focused update on dual antiplatelet therapy in coronary artery disease developed in collaboration with EACTS The Task Force for dual antiplatelet therapy in coronary artery disease of the European Society of Cardiology (ESC) and of the European Association for CardioThoracic Surgery (EACTS). Eur Heart J 2018;39(3):213-260.

4. Thygesen $\mathrm{K}, \mathrm{Alpert} J \mathrm{~S}$, Jaffe AS, et al. Writing Group on the Joint ESC/ACCF/AHA/WHF Task Force for the Universal Definition of Myocardial Infarction, ESC Committee for Practice Guidelines. Third universal definition of myocardial infarction. Eur Heart J 2012;33(20):2551-67.

5. Valgimigli M. Pretreatment with P2Y12 inhibitors in non-ST-segment-elevation acute coronary syndrome is clinically justified. Circulation 2014;130:1891-903.

6. Collet JP, Silvain J, Bellemain-Appaix A, Montalescot G. Pretreatment with P2Y12 inhibitors in non-ST-Segment-elevation acute coronary syndrome: an outdated and harmful strategy. Circulation 2014;130:1904-14.

7. Montalescot G, Bolognese L, Dudek D, et al. Pretreatment with prasugrel in non-ST-segment elevation acute coronary syndromes. N Engl J Med 2013;369:999-1010.

8. Cannon CP, Harrington RA, James S, Ardissino D et al. PLATelet inhibition and patient Outcomes Investigators. Comparison of ticagrelor with clopidogrel in patients with a planned invasive strategy for acute coronary syndromes (PLATO): a randomized double-blind study. Lancet 2010;375:283-93.

9. Costa F, van Klaveren D, James S, et al. Derivation and validation of the predicting bleeding complications in patients undergoing stent implantation and subsequent dual antiplatelet therapy (PRECISE-DAPT) score: a pooled analysis of individual-patient datasets from clinical trials. Lancet 2017;389:1025-34.

10. Kirchhof K, Benussi S, Kotecha D, et al. 2016 ESC Guidelines for the management of atrial fibrillation developed in collaboration with EACTS The Task Force for the management of atrial fibrillation of the European Society of Cardiology (ESC) Developed with the special contribution of the European Heart Rhythm Association (EHRA) of the ESC Endorsed by the European Stroke Organization (ESO). European Heart Journal (2016) 37, 2893-962.

11. Fiedler KA, Maeng M, Mehilli J, et al. Duration of triple therapy in patients requiring oral anticoagulation after drug-eluting stent implantation: the ISAR-TRIPLE trial. J Am Coll Cardiol 2015; 65:1619-29.

12. Dewilde WJ, Oirbans T, Verheugt FW, et al. JM, WOEST Study Investigators. Use of clopidogrel with or without aspirin in patients taking oral anticoagulant therapy and undergoing percutaneous coronary intervention: an open-label, randomized, controlled trial. Lancet 2013;381:1107-15.

13. Cannon PC, Deepak L. Bhatt LD, et al. Dual Antithrombotic Therapy with Dabigatran after $\mathrm{PCl}$ in Atrial Fibrillation. N Engl J Med 2017; 377:1513-24

14. Gibson CM, Mehran R, Bode C, et al. Prevention of bleeding in patients with atrial fibrillation undergoing $\mathrm{PCl}$. N Engl J Med 2016;375:2423-34

15. Yeh RW, Secemsky EA, Kereiakes DJ, et al. Development and validation of a prediction rule for benefit and harm of dual antiplatelet therapy beyond 1 year after percutaneous coronary interventions. JAMA 2016;315(16):1735-49. 